\title{
Spatial distribution of soils determines export of nitrogen and dissolved organic carbon from an intensively managed agricultural landscape
}

\author{
T. Wohlfart ${ }^{1}$, J.-F. Exbrayat ${ }^{1,2}$, K. Schelde ${ }^{3}$, B. Christen ${ }^{3}$, T. Dalgaard ${ }^{3}$, H.-G. Frede ${ }^{1}$, and L. Breuer ${ }^{1}$ \\ ${ }^{1}$ Institute for Landscape Ecology and Resources Management (ILR), Research Centre for BioSystems, Land Use and \\ Nutrition (IFZ), Justus-Liebig Universität Gießen, Germany \\ ${ }^{2}$ Climate Change Research Centre, University of New South Wales, Sydney, New South Wales, Australia \\ ${ }^{3}$ Department of Agroecology, Aarhus University, Denmark \\ Correspondence to: L. Breuer (lutz.breuer@umwelt.uni-giessen.de)
}

Received: 29 March 2012 - Published in Biogeosciences Discuss.: 25 June 2012

Revised: 28 September 2012 - Accepted: 22 October 2012 - Published: 15 November 2012

\begin{abstract}
The surrounding landscape of a stream has crucial impacts on the aquatic environment. This study pictures the hydro-biogeochemical situation of the Tyrebækken creek catchment in central Jutland, Denmark. The intensively managed agricultural landscape is dominated by rotational croplands. The small catchment mainly consist of sandy soil types besides organic soils along the streams. The aim of the study was to characterise the relative influence of soil type and land use on stream water quality. Nine snapshot sampling campaigns were undertaken during the growing season of 2009. Total dissolved nitrogen (TDN), nitrate $\left(\mathrm{NO}_{3}^{-}\right)$, ammonium nitrogen and dissolved organic carbon (DOC) concentrations were measured, and dissolved organic nitrogen (DON) was calculated for each grabbed sample. Electrical conductivity, $\mathrm{pH}$ and flow velocity were measured during sampling. Statistical analyses showed significant differences between the northern, southern and converged stream parts, especially for $\mathrm{NO}_{3}^{-}$concentrations with average values between $1.4 \mathrm{mg} \mathrm{N}^{-1}$ and $9.6 \mathrm{mg} \mathrm{N}^{-1}$. Furthermore, throughout the sampling period DON concentrations increased to $2.8 \mathrm{mg} \mathrm{N}^{-1}$ in the northern stream contributing up to $81 \%$ to TDN. Multiple-linear regression analyses performed between chemical data and landscape characteristics showed a significant negative influence of organic soils on instream $\mathrm{N}$ concentrations and corresponding losses in spite of their overall minor share of the agricultural land (12.9\%). On the other hand, organic soil frequency was positively correlated to the corresponding DOC concentrations. Croplands
\end{abstract}

also had a significant influence but with weaker correlations. For our case study we conclude that the fractions of coarse textured and organic soils have a major influence on $\mathrm{N}$ and DOC export in this intensively used landscape. Meanwhile, the contribution of DON to the total $\mathrm{N}$ losses was substantial.

\section{Introduction}

Agricultural land use has been found responsible for major nutrient losses from land to river systems and estuaries worldwide (Vitousek et al., 1997). Nitrate $\left(\mathrm{NO}_{3}^{-}\right)$is described as the main source of nitrogen $(\mathrm{N})$ losses from cultivated land, because it is the most important growth regulating nutrient and is often applied in excess to guarantee optimal crop yields (van Kessel et al., 2009; Martin et al., 2004; Randall and Mulla, 2001; Ruiz et al., 2002a; Steenvoorden et al., 2002). The amount of $\mathrm{NO}_{3}^{-}$leaching into water bodies depends on dry and wet climatic cycles (Randall, 1998). During dry periods $\mathrm{NO}_{3}^{-}$accumulates in soils before being released under wet conditions, even after many years (Randall and Mulla, 2001). More generally, $\mathrm{N}$ losses naturally show a large spatial and temporal variability with minimum losses occurring in summer as a result of biological uptake (Edwards et al., 1985). For example, Vagstad et al. (2004) described N losses ranging from 5 to $75 \mathrm{~kg} \mathrm{ha}^{-1} \mathrm{yr}^{-1}$ in different Baltic regions, with the highest losses corresponding to cropland on sandy soils. Indeed, soil physicochemical properties such as 
texture or organic content play an important role on $\mathrm{N}$ losses. Recently, researchers have put more emphasis on studying the contribution of dissolved organic nitrogen (DON) to the $\mathrm{N}$ balance of landscapes (Mattson et al., 2009; Cooper et al., 2007; Ghani et al., 2007; van Kessel et al., 2009; Neff et al., 2003, 2002). Hedin et al. (1995) found that organic N represents a large part of the total $\mathrm{N}$ losses from forest ecosystems, which was also described in other studies (van Breemen, 2002; Cooper et al., 2007; van Kessel et al., 2009; Neff et al., 2003, 2002). It was also found that DON can be used as N source by many plant species (Näsholm et al., 2009) and therefore could also play a substantial role in N flows of agricultural systems.

Cooper et al. (2007) pointed out that the release of DON (and DOC) is "strongly influenced by a wide range of hydrometeorological factors". As DON includes labile and recalcitrant compounds (Neff et al., 2003) and has different retention times in soil and water, corresponding losses can substantially vary between different watersheds. Therefore, there is a need to better understand the fundamental role of DON in agricultural systems (Ghani et al., 2007; van Kessel et al., 2009) and in the global N cycle (see review by Durand et al., 2011), including its preferential flow pathways and biological degradation mechanisms (Perakis, 2002).

In this study, we focused on the $\mathrm{N}$ and carbon (C) fluxes in the Tyrebækken stream (Denmark) and the influence of land use and soil properties on stream chemistry. Agriculture represents a large sector of Danish economy due to a suitable climate and relatively good soils. Manure is the main fertiliser source for agricultural production (Dalgaard et al., 2011b) and represents more than $80 \%$ of the $\mathrm{N}$ source in Danish streams, lakes and coastal waters (Kronvang et al., 2005, 2008; National Environmental Research Institute, 2006). We investigated the fractions of dissolved inorganic nitrogen (DIN) and DON within total dissolved nitrogen (TDN) concentrations and fluxes in the stream water, respectively. As DON is linked to DOC by often sharing the same origin of organic matter, DOC values were also studied. The main concern of this investigation concentrated on answering two questions:

1. What is the relative influence on stream chemistry of land use and soil properties?

2. How big is the contribution of DON to TDN losses from agriculture-dominated land?

In order to unravel the impact of soil properties and land use on in-stream chemistry, measurements of different $\mathrm{C}$ and $\mathrm{N}$ solutes with a high spatial and temporal resolution are required. Furthermore, to get a general overview on seasonal trends in effects of nutrient export, flushing rainfall events need to be excluded. Therefore, in our study we performed "snapshot" sampling campaigns during stable flow conditions (Grayson et al., 1997).

\section{Materials and methods}

\subsection{Study area}

The study site is located south of Bjerringbro in central Jutland, Denmark. Two streams run through the investigated area from the east towards north-west (Fig. 1; Hutchings et al., 2004). They converge to form the Tyrebækken stream that ultimately reaches the Gudenå River approximately $3 \mathrm{~km}$ downstream of the studied area. The total catchment area is 842.7 ha and outlet coordinates are $56^{\circ} 35^{\prime} 14^{\prime \prime} \mathrm{N}$ and $9^{\circ} 65^{\prime} 09^{\prime \prime} \mathrm{E}$. According to the available $2 \times 2 \mathrm{~m} \mathrm{DEM}$ digitised for the NitroEurope project (Dalgaard et al., 2012; Hansen, 2004), elevation ranges from 25 to $58 \mathrm{~m}$ a.s.l. and topography is gentle with a mean slope of $3.7 \%$, although local maximum reaches $21.4 \%$. The mean annual rainfall in the area is about $712 \mathrm{~mm}$ with a corresponding mean evapotranspiration of $555 \mathrm{~mm}$ per year. Mean annual temperature is $7.7^{\circ} \mathrm{C}$ (PlanteInfo, 2011).

As presented in Fig. 1, three river parts were analysed: the northern branch (sampling points 1 to 6 ), the southern branch (points 11 to 20) and the downstream converged part (points 21 to 24). As summarised in Table 1 and depicted in Fig. 1, land use is dominated by $90 \%$ of intensive farming, primarily arable cropland in rotation $(70 \%)$. Pasture is the second most frequent land cover $(20 \%)$, totally dominating the land use along the stream (Cellier et al., 2011). The average fertilisation in the area is $80 \mathrm{~kg} \mathrm{~N} \mathrm{ha}^{-1} \mathrm{yr}^{-1}$ in the form of livestock manure (equal amounts of pig and cattle slurry), and $74 \mathrm{~kg} \mathrm{Nha}^{-1} \mathrm{yr}^{-1}$ in the form of synthetic fertilisers with a modelled average $\mathrm{NO}_{3}^{-}$leaching equal to $58 \mathrm{~kg} \mathrm{~N} \mathrm{ha}^{-1} \mathrm{yr}^{-1}$ (Dalgaard et al., 2011a), correlating to the typical cropping and management practices in this part of Denmark (moraine plateaus with arable land dominated by winter wheat cereals, and with permanent grassland on the lowland organic soils; Dalgaard et al., 2012; Höll et al., 2002). According to Dalgaard et al. (2012) atmospheric $\mathrm{N}$ deposition for the Bjerringbro area derived from EMEP (2012) was around $12 \mathrm{~kg} \mathrm{ha}^{-1} \mathrm{yr}^{-1}$, adding another $8 \%$ of total $\mathrm{N}$ input, which does not significantly change the overall $\mathrm{N}$ budget. The four dominant soil textures are coarse sandy clay $(27 \%)$, coarse clayey sand (26\%), fine clayey sand $(24 \%)$ and $13 \%$ with soil organic matter predominant (Table 1). As illustrated in Fig. 2 (Dalgaard et al., 2002), organic soils are mostly found near streams. The northern part is dominated by coarse and fine clayey sands whilst coarse sandy clay dominates the southern part (Fig. 2).

\subsection{Sample collection and analyses}

A total of nine snapshot sampling campaigns (Grayson et al., 1997) were carried out in 2009. Sampling periods corresponded to stable flow conditions in April (20th, 24th and 27th), August (4th, 11th, 13th), and September (10th, 17 th and 25th). Twenty different locations at an approximate 


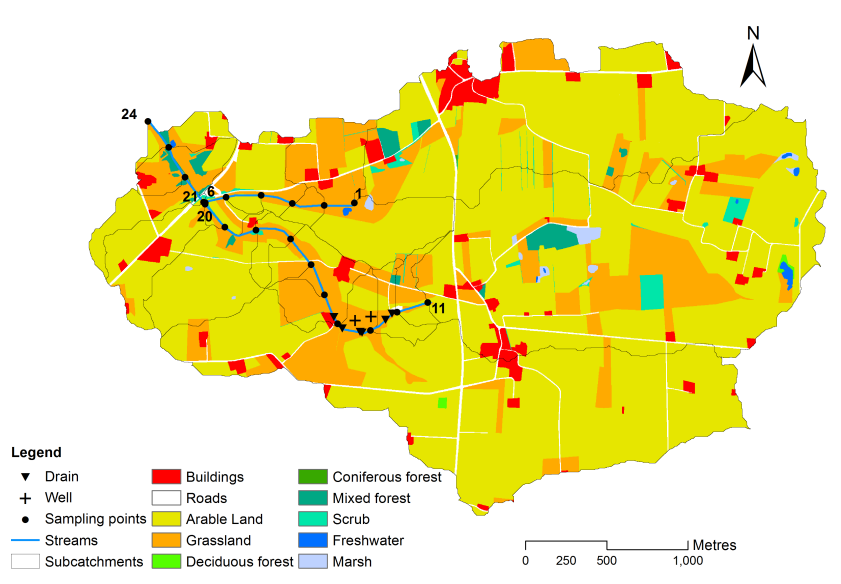

Fig. 1. Land use distribution over the Bjerringbro study area with stream network, delineated subcatchments and selected sampling site numbers along the stream (digitized for the NitroEurope project; Dalgaard et al., 2012).

spacing of $200 \mathrm{~m}$ along the stream were sampled during each campaign (Fig. 3). Furthermore, six drains $(T)$ that discharge directly into the southern stream were analysed as well as two nearby groundwater wells (GW) (Fig. 3). Geographic coordinates of the sampled waypoints were captured with a global positioning system (Garmin eTrex) and imported into a geographic information system (ArcGIS 9.3). The $2 \times 2 \mathrm{~m}$ DEM from the Bjerringbro area was used to delineate and calculate the upstream contributing area corresponding to each sampled point (Fig. 3). The sampling protocol included measuring in-stream flow velocity with an electromagnetic flow meter (FloMate 2000, Marsh McBirney, Frederick, US) and electric conductivity (EC) with a portable instrument (pH/cond 340i, WTW, Weilheim, Germany). Discharge $Q$ $\left[1 \mathrm{~s}^{-1}\right]$ was computed based on stream velocity and the crosssectional area of the stream bed. Triplicates of grabbed water samples were filled in $100 \mathrm{ml}$ low-density polyethylenebottles at each waypoint on each sampling day. One bottle was stored cold for immediate analyses whilst two bottles were frozen for later analyses at the laboratory of the JustusLiebig-Universität, Gießen.

Samples were filtered and analysed at Aarhus University within $24 \mathrm{~h} . \mathrm{NO}_{3}^{-}$and ammonium $\left(\mathrm{NH}_{4}^{+}\right)$concentrations were measured with a field photometer (Spectroquant ${ }^{\circledR}$ Multy, Merck, Darmstadt, Germany) and converted to corresponding $\mathrm{NO}_{3}^{-}-\mathrm{N}$ and $\mathrm{NH}_{4}^{+}-\mathrm{N}$ concentrations. $\mathrm{pH}$ was measured with the same portable instrument as EC. Samples that were stored frozen were later filtered with a $0.45 \mu \mathrm{m}$ filter and analysed for DOC and TDN with a liquiTOC analyser (Elementar Analysensysteme GmbH, Hanau, Germany) based on high temperature oxidation.

DON was finally computed as the difference between TDN and DIN. Because measured $\mathrm{NH}_{4}^{+}$concentrations were often under the detection limit of $0.02 \mathrm{mgl}^{-1}$ (63\% of

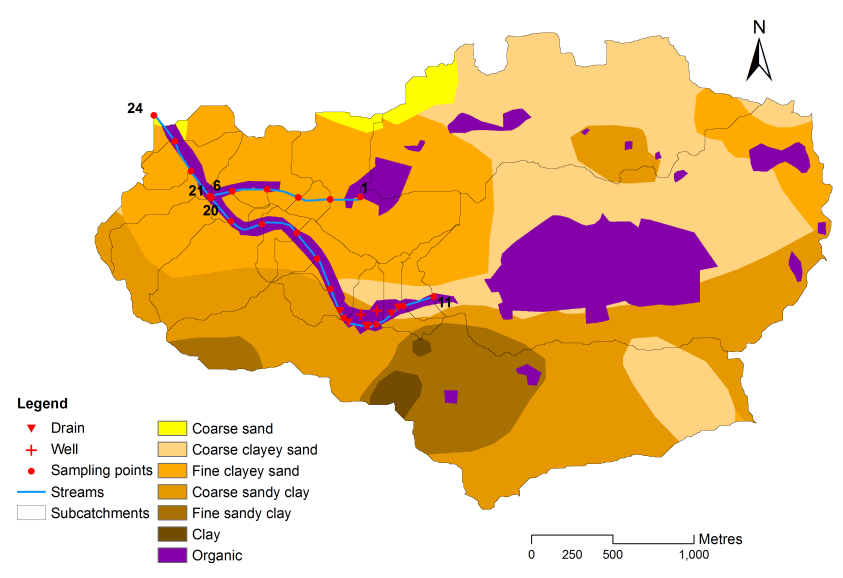

Fig. 2. Soil type distribution over the Bjerringbro study area with stream network, delineated subcatchments and selected sampling site numbers along the stream (based on the soil type map from Dalgaard et al., 2002).

measurements) or just above $\left(<0.05 \mathrm{mg}^{-1}\right.$ in $93 \%$ of measurements), DIN was assumed to be equivalent to $\mathrm{NO}_{3}^{-}-\mathrm{N}$ concentrations. Specific loads $\left[\mathrm{g} \mathrm{ha}^{-1} \mathrm{~d}^{-1}\right.$ ] of $\mathrm{NO}_{3}^{-}-\mathrm{N}$, DON and DOC were calculated by multiplying concentrations with daily specific discharge. They refer to yields (loads, or the mass of nutrient exported) per unit of area and allow comparing losses from catchments of different size.

\subsection{Statistical analysis}

To determine significant spatial and temporal differences of $\mathrm{C}$ and $\mathrm{N}$ solutes, t-tests between different stream sections and sampling periods at a $5 \%$ level were carried out. Furthermore, Pearson correlation coefficients were calculated between the three components $\left(\mathrm{NO}_{3}^{-}-\mathrm{N}, \mathrm{DON}, \mathrm{DOC}\right)$ for concentrations and specific loads to check for inter-dependence of solute dynamics.

To investigate the influence of land use and soils on stream chemistry, multivariate regression analyses were made with the "backwards" method using SPSS 15.0.1 (2006) (Jobson, 1991), defining measured stream chemistry at each waypoint as dependent variables. The independent variables were the areal fraction of contributing area covered by cropland, the portions covered by coarse clayey sandy soils and portion covered and by organic soils, two GIS-derived landscape characteristics (mean slope and mean topographic wetness index (TWI) of each sub-basin) and the sampling period (April, August, September). TWI (Wilson and Gallant, 2000) is a measure of topographic control on hydrological processes that considers the local upslope catchment area and its slope. It was calculated with the spatial analyst toolbox of ArcGIS 9.3 as TWI $=\ln \left(A_{\mathrm{s}} / \tan \beta\right)$, with $A_{\mathrm{s}}$ being the specific catchment area and $\beta$ the slope gradient. We only report coefficient of determinations $\left(R^{2}\right)$ and standardised beta coefficients as we focus on the relative importance 
Table 1. Upstream area with related land use and soil type in the top layer calculated with ArcGIS. Point numbers correspond to Figs. 1, 2 and 3 .

\begin{tabular}{lrrrrrrrrr}
\hline Point & $\begin{array}{r}\text { Upstream } \\
\text { area } \\
{[\text { ha] }}\end{array}$ & $\begin{array}{r}\text { Cropland } \\
{[\%]}\end{array}$ & $\begin{array}{r}\text { Pasture } \\
{[\%]}\end{array}$ & $\begin{array}{r}\text { Forest } \\
{[\%]}\end{array}$ & $\begin{array}{r}\text { Wetland } \\
{[\%]}\end{array}$ & $\begin{array}{r}\text { Coarse } \\
\text { clayey sand } \\
{[\%]}\end{array}$ & $\begin{array}{r}\text { Coarse } \\
\text { sandy clay } \\
{[\%]}\end{array}$ & $\begin{array}{r}\text { Fine } \\
\text { clayey sand } \\
{[\%]}\end{array}$ & $\begin{array}{r}\text { Organic } \\
{[\%]}\end{array}$ \\
\hline 01 & 153.0 & 72.0 & 14.1 & 1.9 & 0.1 & 59.7 & 8.1 & 18.6 & 6.4 \\
06 & 227.1 & 66.5 & 21.6 & 1.3 & 0.2 & 40.2 & 5.5 & 41.1 & 7.2 \\
11 & 263.2 & 68.3 & 20.0 & 1.7 & 1.1 & 35.9 & 22.0 & 13.1 & 27.5 \\
20 & 559.2 & 72.3 & 19.5 & 1.0 & 0.6 & 22.8 & 36.6 & 12.5 & 15.9 \\
21 & 809.0 & 70.9 & 19.7 & 1.0 & 0.4 & 27.0 & 28.2 & 21.7 & 13.0 \\
24 & 842.7 & 70.0 & 20.3 & 1.3 & 0.4 & 26.0 & 27.4 & 23.9 & 12.9 \\
\hline
\end{tabular}

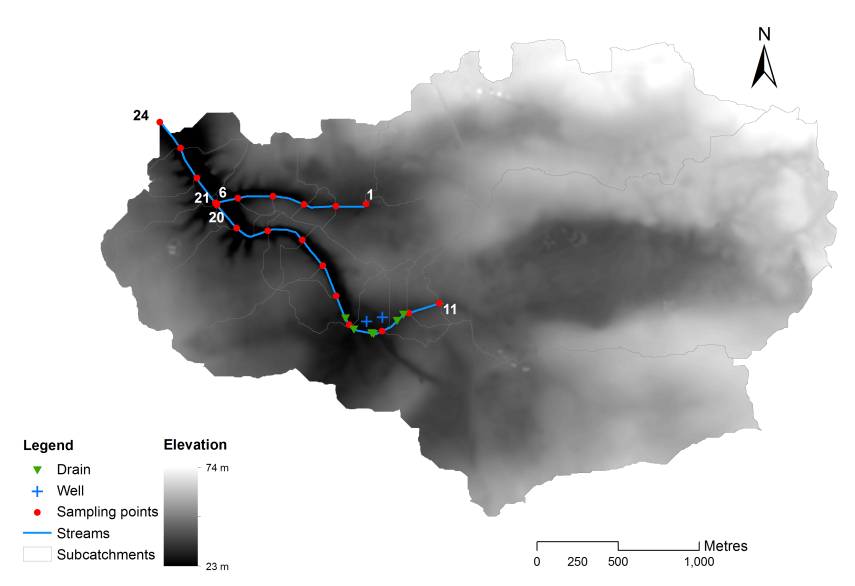

Fig. 3. Elevation model $(2 \times 2 \mathrm{~m}$, based on the airborne laserscanning by Hansen, 2004) with locations of sampling points along the three stream sections with corresponding subcatchments. $\mathrm{Nu}$ meric labels indicate the number of the sampling point.

of independent variables rather than predicting dependent variables. To exclude multicollinearity and autocorrelation of residuals, both tolerance and Durbin-Watson coefficients were checked. Multicollinearity can be expected with a tolerance value smaller than 0.1 (Jobson, 1991). None of the regression coefficients had tolerance values below this level. For the Durbin-Watson coefficient, values below 1 or above 3 point to strong autocorrelation. Durbin-Watson coefficients of all regression analyses varied between 1 and 1.5, indicating a moderate positive autocorrelation of residuals. This is often observed when time series are analysed. In particular, snapshot sampling is very sensitive to autocorrelation as waypoints are located in vicinity to each other and concentrations measured upstream are likely to impact conditions downstream. However, as we used the regression analyses for identifying relevant independent variables rather than predicting dependent variables, we assume to observe the basic conditions of regression analyses.

\section{Results}

Precipitation during the sampling period varied within the span of long-term trends. Whilst April was substantially drier than usual with only $11 \mathrm{~mm}(-71 \%)$ precipitation instead of a long-term monthly mean of $38 \mathrm{~mm}$, July and August saw more rainfall than usual with $90 \mathrm{~mm}(+40 \%)$ and $82 \mathrm{~mm}$ $(+28 \%)$, respectively, in relation to a mean of $64 \mathrm{~mm}$ for both months. September was drier than usual with $45 \mathrm{~mm}$ $(-33 \%)$ instead of its monthly mean of $67 \mathrm{~mm}$.

Measured EC and pH are presented in Table 2. Mean EC ranged from 351 to $418 \mu \mathrm{S} \mathrm{cm}^{-1}$ and mean $\mathrm{pH}$ values from 7.2 to 7.7 in accordance with typically observed values in Danish streams (National Environmental Research Institute, 2006).

Discharge of up to $10.01 \mathrm{~s}^{-1}$ in the northern stream was low in comparison to the southern branch. The discharge from the source of the southern stream towards the catchment outlet (including the converged part) increased from $2.11 \mathrm{~s}^{-1}$ to $25.41 \mathrm{~s}^{-1}$ for the southern stream part and from $16.81 \mathrm{~s}^{-1}$ to $37.61 \mathrm{~s}^{-1}$ for the converged part. Mean runoff during the sampling period is given in Table 2 for all three stream sections.

As shown in Fig. 4a, $\mathrm{NO}_{3}^{-}-\mathrm{N}$ concentrations ranged from 0.4 to $11.3 \mathrm{mg} \mathrm{N}^{-1}$ for all three stream sections. Meanwhile, DON concentrations (Fig. 4c) showed the highest values in the northern stream between $<0.01$ and $4.3 \mathrm{mg} \mathrm{N}^{-1}$. On the contrary, DOC concentrations (Fig. 4e) were lowest in the northern part with concentrations from 5.9 to $11.5 \mathrm{mg} \mathrm{Cl}^{-1}$.

Figure $4 \mathrm{~b}, \mathrm{~d}$ and $\mathrm{f}$ show the corresponding loads of the three stream solutes. The northern branch detected highest loads of $\mathrm{NO}_{3}^{-}-\mathrm{N}$ with up to $48.5 \mathrm{~g} \mathrm{~N} \mathrm{ha}^{-1} \mathrm{~d}^{-1}$ as well as highest DON loads of up to $16.0 \mathrm{~g} \mathrm{Nha}^{-1} \mathrm{~d}^{-1}$. Along with observed DOC concentrations, loads were higher in the southern stream with up to $59.1 \mathrm{~g} \mathrm{C} \mathrm{ha}^{-1} \mathrm{~d}^{-1}$.

Distinct differences in concentrations between stream sections could be observed from the measurements. As shown in Fig. 4a, the northern part always showed significantly higher $\mathrm{NO}_{3}^{-}-\mathrm{N}$ concentrations than the other streams. Furthermore, the same stream section also depicted higher DON concentrations than the two other ones in August and September. 
Table 2. Mean values of $\mathrm{pH}$, EC and discharge $(Q)$ for April, August and September for the northern stream, southern stream and after convergence.

\begin{tabular}{|c|c|c|c|c|c|c|c|c|c|}
\hline & \multicolumn{3}{|c|}{$\mathrm{pH}[-]$} & \multicolumn{3}{|c|}{$\mathrm{EC}\left[\mu \mathrm{S} \mathrm{cm}^{-1}\right]$} & \multicolumn{3}{|c|}{$Q\left[1 \mathrm{~s}^{-1}\right]$} \\
\hline & April & August & September & April & August & September & April & August & September \\
\hline Northern part & $7.4^{\mathrm{a}, \mathrm{x}}$ & $7.2^{\mathrm{a}, \mathrm{x}}$ & $7.3^{\mathrm{a}, \mathrm{x}}$ & $351^{\mathrm{a}, \mathrm{x}}$ & $407^{\mathrm{b}, \mathrm{x}}$ & $405^{\mathrm{b}, \mathrm{x}}$ & $5.8^{\mathrm{a}, \mathrm{x}}$ & $6.0^{\mathrm{a}, \mathrm{x}}$ & $5.3^{\mathrm{a}, \mathrm{x}}$ \\
\hline Southern part & $7.5^{\mathrm{a}, \mathrm{x}}$ & $7.4^{\mathrm{b}, \mathrm{y}}$ & $7.4^{\mathrm{a}, \mathrm{b}, \mathrm{x}}$ & $402^{\mathrm{a}, \mathrm{y}}$ & $418^{\mathrm{a}, \mathrm{x}}$ & $405^{\mathrm{b}, \mathrm{y}}$ & $14.7^{\mathrm{a}, \mathrm{y}}$ & $10.0^{\mathrm{b}, \mathrm{y}}$ & $10.7^{\mathrm{a}, \mathrm{b}, \mathrm{y}}$ \\
\hline Converged part & $7.7^{\mathrm{a}, \mathrm{y}}$ & $7.6^{\mathrm{a}, \mathrm{z}}$ & $7.6^{\mathrm{b}, \mathrm{y}}$ & $367^{\mathrm{a}, \mathrm{x}, \mathrm{y}}$ & $409^{\mathrm{a}, \mathrm{x}}$ & $413^{\mathrm{b}, \mathrm{z}}$ & $31.9^{\mathrm{a}, \mathrm{z}}$ & $20.9^{b, z}$ & $26.5^{\mathrm{c}, \mathrm{z}}$ \\
\hline
\end{tabular}

a,b,c indicate significant differences between April, August and September measurements. ${ }^{\mathrm{x}, \mathrm{y}, \mathrm{z}}$ indicate significant differences between northern part, southern part and converged part.

Regarding DOC concentrations, significantly higher values were measured in the southern stream for all three months. In the northern stream, the high $\mathrm{NO}_{3}^{-}-\mathrm{N}$ concentrations remained stable throughout the complete sampling period, whereas DON concentrations increased significantly between April and September (Fig. 4c). Similarly, DOC concentrations were significantly lower in April than in August and September.

Considering losses, DON loads were significantly lower in April than in August and September, whereas $\mathrm{NO}_{3}^{-}-\mathrm{N}$ and DOC loads remained stable in the northern part over the observation periods.

In the southern stream section, the $\mathrm{NO}_{3}^{-}-\mathrm{N}$ concentrations were significantly higher in April in comparison to the latter sampling periods. DON concentrations and losses in this stream section increased significantly between April and the end of summer. DOC concentrations were significantly higher in September than in April and August. Furthermore, $\mathrm{NO}_{3}^{-}-\mathrm{N}$ loads were significantly higher in April than in August and September. Significant differences in DOC loads were found for all three months in the southern part.

The converged stream part showed significantly rising $\mathrm{NO}_{3}^{-}-\mathrm{N}$ loads from August to September. Furthermore DOC loads declined significantly from April to August, whereas no significant differences were found between August and September. All measured concentrations and DON loads showed no significant differences between the three sampling periods.

The drains sampled were all located in the southern subcatchment, as in the northern sections no such drains could be found. $\mathrm{NO}_{3}^{-}-\mathrm{N}$ concentrations in April $\left(\sim 2 \mathrm{mg} \mathrm{N}^{-1}\right)$ were higher than in August $\left(\sim 0.5 \mathrm{mg} \mathrm{N}^{-1}\right)$ and declined in September to concentrations around $1.5 \mathrm{mg} \mathrm{N}^{-1}$ (Fig. 6). Groundwater well concentrations were in the range of drains. Meanwhile, DON and DOC showed neither significant temporal nor spatial differences throughout the sampling periods, apart from single drains peaking in concentration during the third snapshot sampling in April and the first one in August. Multivariate regression analyses demonstrated a significant influence of organic and sandy soils on stream chemistry. $\mathrm{NO}_{3}^{-}-\mathrm{N}$ concentrations and loads are negatively correlated with the occurrence of organic soils, while sandy soils

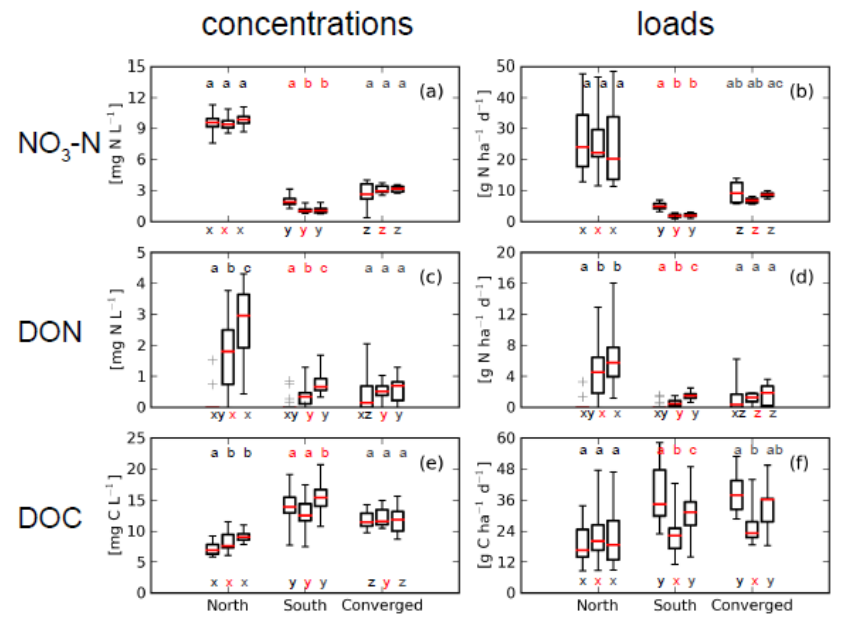

Fig. 4. Boxplots of measured $\mathrm{NO}_{3}^{-}-\mathrm{N}(\mathbf{a}$ and $\mathbf{b}), \mathrm{DON}(\mathbf{c}$ and $\mathbf{d})$ and DOC (e and $\mathbf{f}$ ) concentrations and loads for the northern, southern and converged part. Each group of three boxes corresponds to values measured in April, August and September, respectively. Markers indicate quartiles. In cases where most of the measured values were under detection limits, remaining single values are shown with crosses. Letters a, b and c above markers indicate significant differences between the mean values of April, August and September, whereas letters $\mathrm{x}, \mathrm{y}$ and $\mathrm{z}$ denote significant differences between the three stream branches referring to one sampling period. Colours indicate the compared groups of either date or stream section.

showed positive correlations, indicated by standardized beta coefficients of -0.55 and -0.57 for organic soils and 0.48 and 0.45 for coarse clayey sand, respectively (Table 3). For DON we found positive correlations with both the sampling date and the portion of contributing area covered by sandy soils. The sampling period had the most significant influence on DON concentrations and loads with beta coefficients of 0.47 and 0.38 , respectively. DOC concentrations showed a positive correlation with organic soils while DOC loads positively correlated with arable cropland. The distribution of organic soils seemed to have the most important influence on DOC concentrations as illustrated by a high beta coefficient of 0.70. The two topographical indicators (mean TWI and mean slope) had the lowest beta values, probably due to the uniformly gentle topography. 
Table 3. Corrected $R^{2}$ and standardized beta coefficients of multivariate regression analyses (n.s. = not significant, TWI = topographic wetness index).

\begin{tabular}{|c|c|c|c|c|c|c|c|c|}
\hline & $\begin{array}{c}R^{2} \\
\text { corrected }\end{array}$ & $\begin{array}{c}\text { Soil } \\
\text { (Organic) }\end{array}$ & $\begin{array}{r}\text { Soil } \\
\text { (Coarse } \\
\text { clayey sand) }\end{array}$ & $\begin{array}{r}\text { Land use } \\
\text { (Arable } \\
\text { Cropland) }\end{array}$ & Discharge & $\begin{array}{r}\text { Sampling } \\
\text { period }\end{array}$ & Slope & TWI \\
\hline $\begin{array}{l}\mathrm{NO}_{3}^{-}-\mathrm{N} \\
{\left[\mathrm{mg} \mathrm{N}^{-1}\right]}\end{array}$ & 0.98 & -0.55 & 0.48 & -0.18 & -0.07 & -0.05 & n.s. & -0.02 \\
\hline $\begin{array}{l}\text { DON } \\
{\left[\mathrm{mg} \mathrm{N}^{-1}\right]}\end{array}$ & 0.47 & -0.24 & 0.25 & -0.17 & n.s. & 0.47 & n.s. & n.s. \\
\hline $\begin{array}{l}\text { DOC } \\
{\left[\mathrm{mg} \mathrm{N}^{-1}\right]}\end{array}$ & 0.68 & 0.70 & n.s. & n.s. & 0.29 & 0.17 & -0.28 & n.s. \\
\hline $\begin{array}{l}\mathrm{NO}_{3}^{-}-\mathrm{N} \\
{\left[\mathrm{g} \mathrm{Nha}^{-1} \mathrm{~d}^{-1}\right]}\end{array}$ & 0.87 & -0.57 & 0.45 & n.s. & n.s. & -0.22 & 0.15 & -0.08 \\
\hline $\begin{array}{l}\text { DON } \\
{\left[\mathrm{g} \mathrm{N} \mathrm{ha}^{-1} \mathrm{~d}^{-1}\right]}\end{array}$ & 0.42 & -0.25 & 0.37 & n.s. & n.s. & 0.38 & n.s. & n.s. \\
\hline $\begin{array}{l}\text { DOC } \\
{\left[\mathrm{g} \mathrm{Nha}^{-1} \mathrm{~d}^{-1}\right]}\end{array}$ & 0.25 & n.s. & -0.18 & 0.36 & n.s. & -0.18 & n.s. & n.s. \\
\hline
\end{tabular}

Furthermore, correlation coefficients were calculated for concentrations and loads to determine relations between the three solutes. We found $\mathrm{NO}_{3}^{-}-\mathrm{N}$ and DON to exhibit a relative strong correlation with respect to concentrations and loads with coefficients of 0.47 and 0.57 , respectively. On the other hand, DON and DOC were poorly correlated with corresponding coefficients of -0.17 and 0.06 for concentrations and loads, respectively. Whilst concentrations of DOC and $\mathrm{NO}_{3}^{-}-\mathrm{N}$ depicted the highest correlation of -0.76 , this relation was not evident for loads $(-0.05)$.

\section{Discussion}

\subsection{Nitrate}

In the Danish stream Tyrebækken, water analyses showed a quite heterogeneous distribution of $\mathrm{NO}_{3}^{-}-\mathrm{N}$ concentrations and fluxes between the three stream sections. In the northern part, they were significantly higher than in the southern part even though the land use distribution according to Table 1 apparently did not vary much. On average $\mathrm{NO}_{3}^{-}-\mathrm{N}$ concentrations measured in the southern part represented about $15 \%$ of the concentrations measured on the same day in the northern part. However, as mentioned in Sect. 2.1, detailed information about site-specific management practices (Dalgaard et al., 2012; Cellier et al., 2011) showed relatively larger areas with extensive grazing (and thereby lower $\mathrm{N}$ fertiliser and manure input) in the northern part, which also included more wet meadows compared to the more steep terrain along the southern stream branch. Despite this, higher $\mathrm{NO}_{3}^{-}-\mathrm{N}$ concentrations were exhibited in the northern branch during summer 2009. As pointed out in many studies (Böhlke and Denver, 1995; Ruiz et al., 2002a; Worrall and Burt, 2001), soils are able to store $\mathrm{N}$, leading to poor correlations between $\mathrm{N}$ losses from agricultural soils and headwater quality. Consequently, $\mathrm{N}$ leaching is affected by past land use and management practices (Hansen et al., 2011, 2012), which varied a lot in this area during the past $300 \mathrm{yr}$ (Caspersen and Fritzbøger, 2002), but a further study of this aspect was out the scope of the present study. Furthermore, the $\mathrm{NO}_{3}^{-}$stored in soils can be released into sub-surface and groundwater after some time. Nutrients are mobilised by mineralisation processes during the growing season when high rates of microbial activity are observed (Böhlke and Denver, 1995; Böhlke, 2002; Schnabel et al., 1993). $\mathrm{NO}_{3}^{-}$leached to shallow groundwater may be steadily released through time periods of a year or more (Martin et al., 2004; Molénat et al., 2002; Ruiz et al., 2002b). As shown by Schiff et al. (2002), $\mathrm{NO}_{3}^{-}$concentrations can be traced back to groundwater charges and might give a correct basis to explain the almost constant $\mathrm{NO}_{3}^{-}-\mathrm{N}$ concentrations measured at sampling point 1 over the whole sampling period.

Meanwhile, C concentrations measured in the southern part were significantly lower in August and September than in April. This was also seen in the concentrations of the drainage outlets found in the southern subcatchment. The lack of rainfall in April may have led to a concentration effect (Poor and McDonnell, 2007) as concentrations measured during wetter periods of August and September were almost two times lower (Fig. 4). In the described study area, Schelde et al. (2012) measured nitrous oxide $\left(\mathrm{N}_{2} \mathrm{O}\right)$ emissions during the study period 2007 to $2009 . \mathrm{N}_{2} \mathrm{O}$ emissions were found to be higher during periods with moist soil, suggesting higher denitrification rates and therefore lower input rates of $\mathrm{NO}_{3}^{-}$with the water draining through soil and into stream water. An intensive field campaign was carried out in April 2009 when $\mathrm{N}_{2} \mathrm{O}$ emissions were found to be relatively low due to dry weather conditions (Schelde et al., 2012) 
leading to the assumption that denitrification rates were low in April. Low denitrification rates in spring 2009 might explain higher $\mathrm{NO}_{3}^{-}$concentrations in the southern stream during August and September 2009. Nevertheless, along with the general shallow groundwater table depth of $0.4 \mathrm{~m}$ observed by Schelde et al. (2012), denitrification is likely to play a dominating factor for $\mathrm{N}$ losses in the area.

Regression analyses showed that $\mathrm{NO}_{3}^{-}-\mathrm{N}$ concentrations and loads significantly depended on soil properties. Organic soils in the upstream area obtained beta coefficients of -0.55 for all three months despite their low proportion of the study area. As summarized in Table 1, there are more organic soils in the contributing area of the southern catchment than in the northern catchment. These soil properties imply a partial immobilization of $\mathrm{NO}_{3}^{-}$(Randall and Mulla, 2001; Schiff et al., 2002) and therefore lower concentrations in stream water. In the same area with organic soils along the southern branch, Schelde et al. (2012) observed that ammonia was more abundant than $\mathrm{NO}_{3}^{-}$in the organic soils, and they found emissions of nitrous oxide to be relatively low at the riparian organic soils. On the other hand, high positive correlations (0.87) between $\mathrm{NO}_{3}^{-}-\mathrm{N}$ concentrations and soil properties were observed for coarse clayey sand that is predominant in the northern branch contributing area. The sandy nature implies a faster drainage of water and nutrients through the soil and a better aeration that favours mineralization and slows down denitrification (Scheffer and Schachtschabel, 2002). Therefore, and in correspondence with earlier Danish studies (Kronvang et al., 2008; Hansen et al., 2012), sandy soils may be the explanation for the higher $\mathrm{NO}_{3}^{-}$concentrations in the northern stream water.

According to the statistical analyses, arable cropland (i.e. excl. grasslands) had a low influence (beta $=-0.19$ ) on $\mathrm{NO}_{3}^{-}$$\mathrm{N}$ concentrations and loads. There was a very similar distribution of land use over the respective contributing areas of the different sampled points. This might be the reason why regression analyses did not assign a higher influence to cropland. Usually, rivers that flow through agricultural land transport much greater $\mathrm{NO}_{3}^{-}$loads in comparison to rivers flowing through forested land (Randall and Mulla, 2001). This contributes to the idea that agricultural practices have the greatest impact on $\mathrm{NO}_{3}^{-}$losses. However, according to Keeney and DeLuca (1993) the fertilizer $\mathrm{N}$ addition is not the important $\mathrm{N}$ contributor to streams. The major part of $\mathrm{NO}_{3}^{-}$supplies rather arises from agricultural practices that enhanced mineralization, leading to soluble $\mathrm{N}$ that can be rapidly transported to the aquatic environment through tile drains. These practices lead to higher losses of $\mathrm{NO}_{3}^{-}$in agricultural dominated areas. Maybe the higher $\mathrm{NO}_{3}^{-}$concentrations in the northern part can be explained by tile drains from the more flat and thereby larger areas of drained agricultural uplands in this area, as compared to the southern part, but this could not be confirmed by the present study. A more elaborated discussion of the hydrology in the area can be found in Dahl et al. (2004), who also discuss the potential effect of clean groundwater from buried valleys, which may affect the $\mathrm{NO}_{3}^{-}$ concentration in the stream, but no systematic difference between the northern and the southern branch of Tyrebækken was found. Furthermore, according to Randall (1998), $\mathrm{NO}_{3}^{-}$ losses are also greatly affected by dry and wet climatic cycles. This might explain the low influence of land use and the higher influence of soil properties on $\mathrm{NO}_{3}^{-}$concentrations in our study.

\subsection{Dissolved organic nitrogen (DON)}

DON was found to be an important part of dissolved $\mathrm{N}$ losses from soils, with concentrations as well as loads increasing through the sampling period. Statistical analyses derived significant differences between the northern and southern stream part for August and September (Fig. 4). Multiple studies have shown that DON accounts for a significant fraction of $\mathrm{N}$ losses to streams of pristine or forested catchments (Campbell et al., 2000; Hedin et al., 1995; Lajtha et al., 1995; Neff et al., 2003). Mean April concentrations for the northern and southern stream part were $0.1 \mathrm{mgl}^{-1}$ with $85 \%$ of them being less than $0.01 \mathrm{mgl}^{-1}$ (Fig. 4). As DON drains through soils, the duration and amount of drainage water are important factors and DON losses depend on rainfall events (Hedin et al., 1995). Even if there is much DON found in the soil, the driving factor that transports the nutrient to surface water may be missing (Hedin et al., 1995; van Kessel et al., 2009). The total precipitation in the Bjerringbro area in April was very low, which may explain the low DON values during this period.

In the review of van Kessel et al. (2009), it was found that the average loss of DON in diverse agricultural systems with mostly light textured soils accounts for $26 \%$ of total soluble $\mathrm{N}$ (mostly $\mathrm{NO}_{3}^{-}$and DON). We found average contributions of 1.2 to $41.2 \%$ in the various study periods and an overall average of $17 \%$ of DON to TDN throughout the entire study (Fig. 5). This is somewhat lower than the typical contribution of DON to TDN in more pristine freshwater ecosystems (Willett et al., 2004). Goodale et al. (2000) found an average of $54 \%$ of DON in total $\mathrm{N}$ exports in forested landscapes with corresponding mean DON losses of $0.7 \mathrm{~kg} \mathrm{ha}^{-1} \mathrm{yr}^{-1}$. Willett et al. (2004) described a contribution of $40 \pm 2 \%$ of DON to total $\mathrm{N}$ in soil solution of Histosols and Spodosols notably under grazed grassland and forested land in Wales and Scotland. Besides, Mattsson et al. (2009) found an averaging proportion of organic $\mathrm{N}$ of $21 \%$ in Danish catchments that were dominated by agricultural land. The study points out a mean DON concentration of $1.1 \mathrm{mg} \mathrm{N}^{-1}$. Siemens and Kaupenjohann (2002) described median DON concentrations of 0.4 to $2.3 \mathrm{mg} \mathrm{N}^{-1}$ for leaching losses of an agricultural site in northwestern Germany and concluded that DON contributes significantly to $\mathrm{N}$ losses from agricultural soils. Considering these findings together with our results, we conclude that DON can contribute substantially to the 

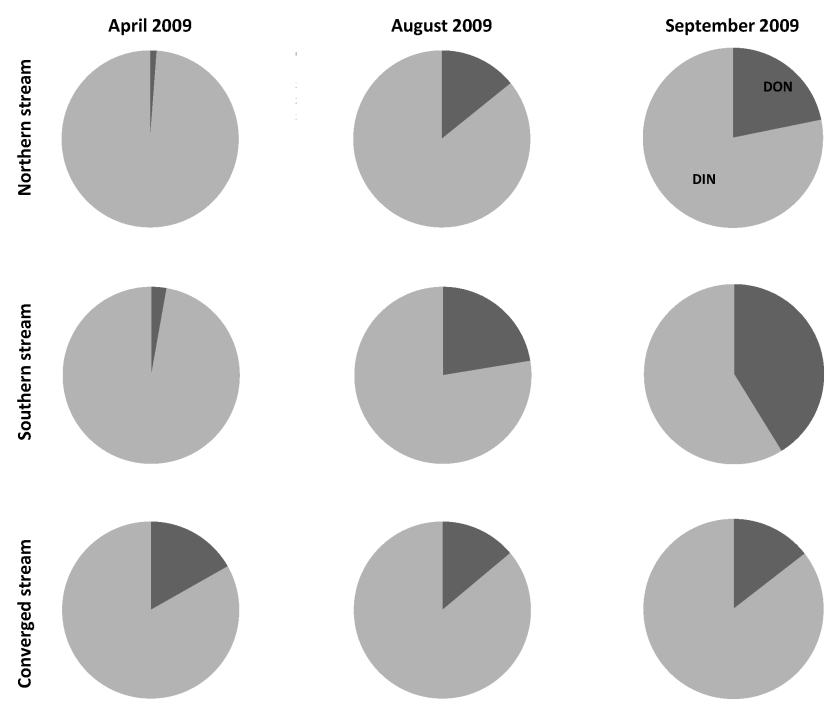

Fig. 5. Contribution (\%) of DON (dark grey) and DIN (light grey) to total dissolved nitrogen losses for every stream section and every sampling period.

total $\mathrm{N}$ budget, even under highly intensive land use systems such as those of the Bjerringbro landscape.

DON exports in our study ranged from $<0.01 \mathrm{~g} \mathrm{ha}^{-1} \mathrm{~d}^{-1}$ to $16.0 \mathrm{~g} \mathrm{ha}^{-1} \mathrm{~d}^{-1}$ and were mostly in the range of observed values reported in other studies. However, little is known on the role of DON in the $\mathrm{N}$ cycle in agricultural soils (Murphy et al., 2000) and flow path dynamics (Willett et al., 2004). Therefore, the connection between the organic $\mathrm{N}$ pool in soil and the in-stream DON export is not well understood. Generally, DON does not vary as much as inorganic $\mathrm{N}$ with biological activity, soil fertility, or season. Campbell et al. (2000) and Goodale et al. (2000) found that DON actually varied little throughout a year. This statement is not compatible with the increasing values from April to September that we observed. In fact, multivariate regression analyses pointed out that sampling time had the highest influence on DON concentrations and loads. Corresponding beta coefficients of 0.51 for DON concentrations and 0.55 for loads reflect the increasing values described above. Neff et al. (2002) pointed out that DON can enter ecosystems through precipitation. Different forms of DON are found in the atmosphere and have the potential to be washed out and flushed into soils and water. Dust might also play an important role as well as components emitted from surrounding agricultural fields (Neff et al., 2002). Wet $\mathrm{N}$ deposition can contain between 25 and $50 \%$ of DON, but direct inputs to freshwater ecosystems are very low (Antia et al., 1991; McHale et al., 2000). Neff et al. (2002) also observed that the organic components of $\mathrm{N}$ found in rain are often labile fractions and very reactive. Due to quick transformations, the reactive $\mathrm{N}$ components in the atmosphere might therefore be more important for local emissions (Neff et al., 2002) and hence contribute
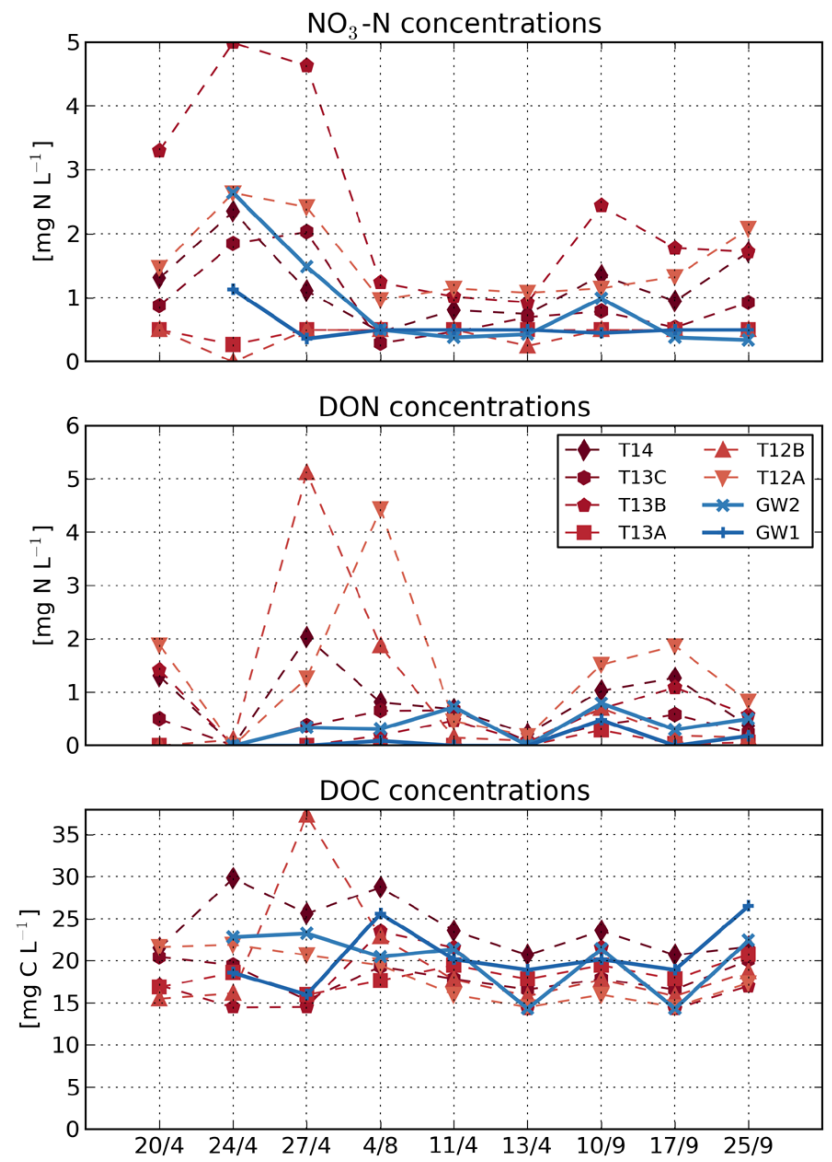

Fig. 6. Measured $\mathrm{NO}_{3}-\mathrm{N}, \mathrm{DON}$ and DOC concentrations $\left[\mathrm{mg} \mathrm{l}^{-1}\right]$ analysed in drains $(T)$ and groundwater wells $(\mathrm{GW})$ during the nine snap shot samplings. The given numbers of the drains refer to the previous in-stream sampling point; letters indicate the position of each drain between two points (A: first, B: second, C: third).

less to freshwater. It is difficult to estimate to what extent these components contribute to surface water input, but they should not be forgotten as a possible path for DON. That is why the ongoing rainfall in July $(89.7 \mathrm{~mm})$ and August $(81.8 \mathrm{~mm})$ might have an influence on the DON concentrations and fluxes at our landscape. The significant contrast to the drier month of April also highlights the importance of the sampling period, and heterogeneities in weather conditions, in the regression.

Regression analyses showed a significant influence of coarse clayey sand on DON concentrations and loads. In general, DON can be affected by biotic factors, like the production of organic matter, and abiotic factors, like soil texture that is responsible for sorption of organic components (Neff et al., 2000). On the other hand, DON losses did not seem to be strongly linked to traditional biotic mechanisms as described for inorganic N (Campbell et al., 2000; Hedin et al., 1995; Willett et al., 2004). Beta coefficients of 0.39 and 0.24 for concentrations and loads, respectively, may give 
an idea about the influence of soil texture on DON losses into streams. As shown in Fig. 4, DON and $\mathrm{NO}_{3}^{-}-\mathrm{N}$ concentrations and loads were higher in the sand-dominated northern stream part, consistent with previous studies (Neff et al., 2003). For DON concentrations, similarly to $\mathrm{NO}_{3}^{-}-\mathrm{N}$, regression analyses assigned negative beta coefficient values for land use $(-0.17)$ and organic soils $(-0.24)$. Moreover, correlations between $\mathrm{NO}_{3}^{-}-\mathrm{N}$ and DON concentrations and loads link the behaviour of the two studied $\mathrm{N}$ components.

\subsection{Dissolved organic carbon (DOC)}

Similarly to the other chemical species studied, measured DOC concentrations and corresponding loads were significantly different between the stream sections. In contrast to $\mathrm{NO}_{3}^{-}$concentrations, DOC values were lower in the northern stream section. Concentrations increased from April to August in the northern stream section, whereas values rose significantly in September in the southern one (Fig. 4). These observations suggest an increasing trend during the growing season, which was also observed by Dawson et al. (2002) and Aitkenhead et al. (1999). These studies reported increasing concentrations in Scottish landscapes from June to November and from May to June, respectively. The early autumn is considered to be the time of maximum DOC export (Cooper et al., 2007; Grieve, 1984; Worrall et al., 2004). The rising trend can result from increasing soil temperature and moisture which are driving factors for decomposition. Moore (2003) measured DOC concentrations ranging from 10 to $30 \mathrm{mg} \mathrm{Cl}^{-1}$ in a boreal landscape with generally increasing values throughout summer. Sand-Jensen and Pedersen (2005) reported DOC concentrations between 4.7 and $18.3 \mathrm{mg} \mathrm{Cl}^{-1}$ in northern Zealand, Denmark, for different sites (agriculture, forest, urban). Mattson et al. (2009) found a mean DOC concentration of $7.2 \mathrm{mg}^{-1}$ while considering 10 Danish streams throughout a year. Generally, the concentrations measured in our study were consistent with these previous results.

Due to the same organic matter origin and similar organic components, DON is often closely linked to the $\mathrm{C}$ cycle (Campbell et al., 2000; Cooper et al., 2007; Ghani et al., 2007; Goodale et al., 2000; van Kessel et al., 2009; Willett et al., 2004). Accordingly, it is assumed that DON and DOC should be equally influenced by soil type or land use. However, we hardly saw any correlations between DOC and DON. Organic soil occurrence explained only little of observed DON concentrations and loads (Table 3), whereas a highly significant influence of organic soils on DOC concentrations was found. The dependency of DOC concentrations on organic soils has been already described by Aitkenhead et al. (1999). Accordingly, Dawson et al. (2008) concluded that the export rate of DOC depends on the carbon soil pool and therefore the organic fraction. They suggested the possibility of assessing mean stream water concentrations from $\mathrm{C}$ pools in soils. Organic soils contain a high proportion of degradable organic matter that can be eventually released by different physicochemical processes into streams (Kennedy et al., 1996). These observations coincide with the results of our study where we find a higher proportion of organic soils in the southern stream part along with higher DOC concentrations and loads.

Results indicated a significant influence of discharge on DOC concentrations, shown also in many other studies (Cooper et al., 2007; Grieve, 1994; Hope et al., 1994; Worrall et al., 2002). Cooper et al. (2007) and Worrall et al. (2002) described the importance of the amount of water flowing through soils and its transit time for flushing $\mathrm{C}$ out of soils. Soil properties can reduce the dissolution of $\mathrm{C}$ into surface waters through sorption on the one hand (Aitkenhead et al., 1999; Cooper et al., 2007; Kennedy et al., 1996), but a faster drainage might limit the ability for adsorption on the other. Rewetting through rain and storm events seems to play an important role on the release of carbon. During these events quick discharge components such as surface and sub-surface runoff rapidly transport $\mathrm{C}$ laterally, reducing time for microbiological degradation in the upper soil horizons (Cooper et al., 2007) and releasing dissolved organic matter into stream water. We assume that the water input by precipitation that influences the in-stream runoff is a driving factor for DOC exports to stream, thus explaining the observed correlation between DOC and discharge. Nevertheless, one has to carefully consider the discharge data obtained with the handheld flow meter and the uncertainty introduced by the evaluation of the cross-section in the transformation of velocity data to volumes.

Interestingly, organic soils have opposite influences on instream concentrations of DOC and DON. With concentrations higher in the southern than in the northern stream, DOC concentrations are positively correlated with the percentage area corresponding to organic soils. Conversely, organic soils have a negative effect on DON concentrations as a result of more adsorption or faster degradation. Actually, adsorption of dissolved organic matter depends on molecular weight, acidic group and aromatic structure (Kaiser and Zech, 2000). The adsorption of DOC and DON also depends on their respective concentrations in the draining water (Lilienfein et al., 2004). According to Lilienfein et al. (2004), at low initial concentrations in soil solution, the soil releases potentially more dissolved organic matter (DOM) than at higher concentrations for which it is more likely to retain these substances. Meanwhile, Lilienfein et al. (2004) also state that adsorption mechanisms of both species are controlled by similar factors. Nevertheless in other studies that compare the behaviour of these two DOM components, conclusions are drawn that the tendencies for adsorption and degradation probably differ between DOC and DON (Michalzik and Matzner, 1999; Kalbitz et al., 2000). It is worth noting that DON has different characteristics in these controlled laboratory experiments than in field studies (Michalzik and Matzner, 1999). Both these previous studies and our current results may indicate 
the existence of at least two different pools of organic matter with heterogeneous composition in the organic soils. However, this would require further field investigations to be confirmed or refuted.

\section{Conclusions}

In spite of the homogeneous distribution of cropland in the area, $\mathrm{C}$ and $\mathrm{N}$ concentrations and loads were significantly different between the different sampled stream parts. We suggest that differences in soil properties are the strongest factor explaining this heterogeneity. As shown by the multiple regression analyses, the distribution of organic soils seemed to have high impact on stream chemistry, especially for DOC exports. Furthermore, dominating sandy soils in the northern part involved a better drainage leading to higher losses of $\mathrm{N}$ components than in the southern part, notably for DON. The land use distribution also had a significant influence on instream chemistry but to a weaker extent. Additionally, DON contributed up to $81 \%$ to the TDN losses during the wetter periods of August and September and might therefore play an important role in the $\mathrm{N}$ budget in intensively managed agricultural landscapes. Meanwhile, the little knowledge on the role of DON in the $\mathrm{N}$ cycle in agricultural soils and flow path dynamics hampers our efforts to connect observed stream water chemistry with agricultural practices and soil properties, and there is a clear need to investigate these aspects in further studies. Some discussion points that could not be answered at the time the study was conducted remain. Sampling efforts were mostly undertaken in the frame of a punctual field work campaign, and we acknowledged that they might not provide a definitive view of in-stream nutrient dynamics.

Acknowledgements. The authors would like to thank the NitroEurope IP for providing financial support. We would like to thank further the University of Aarhus for providing laboratories and working instrumentation and the possibility of working in the study area of Bjerringbro. Further the Viborg Kommune for providing datasets and landowners for allowing us to work on their land. Finally we thank all the involved people for helping with analyses, laboratory instrumentation and data preparation at Aarhus University (AU-Foulum), and the Institute for Landscape Ecology and Resources Management (ILR), Justus-Liebig-Universität Gießen.

Edited by: U. Skiba

\section{References}

Aitkenhead, J. A., Hope, D., and Billett, M. F.: The relationship between dissolved organic carbon in stream water and soil organic carbon pools at different spatial scales, Hydrol. Process., 13, 1289-1302, 1999.

Antia, N. J., Harrison, P. J., and Oliveira, L.: The role of dissolved organic nitrogen in phytoplankton nutrition, cell biology and ecology, Phycologia, 30, 1-89, doi:10.2216/i0031-8884-301-1.1, 1991.

Böhlke, J.-K.: Groundwater recharge and agricultural contamination, Hydrogeol. J., 10, 153-179, doi:10.1007/s10040-001-0183$3,2002$.

Böhlke, J. K. and Denver, J. M.: Combined Use of Groundwater Dating, Chemical, and Isotopic Analyses to Resolve the History and Fate of Nitrate Contamination in Two Agricultural Watersheds, Atlantic Coastal Plain, Maryland, Water Resour. Res., 31, 2319-2339, doi:10.1029/95WR01584, 1995.

Campbell, J. L., Hornbeck, J. W., McDowell, W. H., Buso, D. C., Shanley, J. B., and Likens, G. E.: Dissolved organic nitrogen budgets for upland, forested ecosystems in New England, Biogeochemistry, 49, 123-142, 2000.

Caspersen, O. and Fritzbøger, B.: Long-term landscape dynamics a 300 years case study from Denmark, Danish Journal of Geography, 3, 13-26, 2002.

Cellier, P., Durand, P., Hutchings, N., Dragosits, U., Theobald, M., Drouet, J. L., Oenema, O., Bleeker, A., Breuer, L., Dalgaard, T., Duretz, S., Kros, H., Loubet, B., Olesen, J. E., Mérot, P., Viaud, V., de Vries, W., and Sutton, M. A.: Nitrogen flows and fate in rural landscapes, in: The European Nitrogen Assessment. Sources, Effects and Policy Perspectives, edited by: Sutton, M. A. Howard, C. M., Erisman, J. W., Billen, G., Bleeker, A., Grennfelt, P., van Griensven, H., Grizzetti, B., Cambridge, Cambridge University Press, 229-248, 2011.

Cooper, R., Thoss, V., and Watson, H.: Factors influencing the release of dissolved organic carbon and dissolved forms of nitrogen from a small upland headwater during autumn runoff events, Hydrol. Process., 21, 622-633, doi:10.1002/hyp.6261, 2007.

Dahl, M., Rasmussen, P., Jørgensen, L. F., Erntsen, V., PlatenHallermund, F., and Pedersen, S. S.: The effect of alternative land use on nitrate content in groundwater and surface waters - illustrated by scenario studies. DJF report no. 110 (Markbrug), Foulum, Denmark, 59-70, 2004.

Dalgaard, T., Rygnestad, H., Jensen, J. D., and Larsen, P. E.: Methods to map and simulate agricultural activity at the landscape scale, Danish Journal of Geography, 3, 29-39, 2002.

Dalgaard, T., Hutchings, N., Dragosits, U., Olesen, J. E., Kjeldsen, C., Drouet, J. L., and Cellier, P.: Effects of farm heterogeneity and methods for upscaling on modelled nitrogen losses in agricultural landscapes, Environ. Poll., 159, 3183-3192, 2011 a.

Dalgaard, T., Olesen, J. E., Petersen, S. O., Petersen, B. M., Jørgensen, U., Kristensen, T., Hutchings, N., Gyldenkærne, S., and Hermansen, J. E.: Developments in greenhouse gas emissions and net energy use in Danish agriculture - How to achieve substantial $\mathrm{CO}_{2}$ reductions?, Environ. Poll., 159, 3193-3203, $2011 b$.

Dalgaard, T., Bienkowski, J. F., Bleeker, A., Drouet, J. L., Durand, P., Dragosits, U., Frumau, A., Hutchings, N. J., Kedziora, A., Magliulo, V., Olesen, J. E., Theobald, M. R., Maury, O., Akkal, 
N., and Cellier, P.: Farm nitrogen balances in six European agricultural landscapes - a method for farming system assessment, emission hotspot identification, and mitigation measure evaluation, Biogeosciences Discuss., 9, 8859-8904, doi:10.5194/bgd9-8859-2012, 2012.

Dawson, J. J. C., Billett, M. F., Neal, C., and Hill, S.: A comparison of particulate, dissolved and gaseous carbon in two contrasting upland streams in the UK, J. Hydrol., 257, 226-246, doi:10.1016/S0022-1694(01)00545-5, 2002.

Dawson, J. J. C., Soulsby, C., Tetzlaff, D., Hrachowitz, M., Dunn, S. M., and Malcolm, I. A.: Influence of hydrology and seasonality on DOC exports from three contrasting upland catchments, Biogeochemistry, 90, 93-113, doi:10.1007/s10533-008-9234-3, 2008.

Durand, P., Breuer, L., Johnes, P. J., Billen, G., Butturini, A., Pinay, G., van Grinsven, H., Garnier, J., Rivett, M., Reay, D. S., Curtis, C., Siemens, J., Maberly, S., Kaste, O., Humborg, C., Loeb, R., de Klein, J., Hejzlar, J., Skoulikidis, N., Kortelainen, P., Lepisto, A., and Wright, R.: Nitrogen processes in aquatic ecosystems, in: The European Nitrogen Assessment. Sources, Effects and Policy Perspectives, edited by: Sutton, M. A., Howard, C. M., Erisman, J. W., Billen, G., Bleeker, A., Grennfelt, P., van Griensven, H., and Grizzetti, B., Cambridge, Cambridge University Press, 124146, 2011.

Edwards, A. C., Creasey, J., and Cresser, M. S.: Factors influencing nitrogen inputs and outputs in two Scottish upland catchments, Soil Use Manage., 1, 83-88, doi:10.1111/j.14752743.1985.tb00664.x, 1985.

EMEP: status report 1/2012, "Transboundary acidification, eutrophication and ground level ozone in Europe in 2010", Joint MSCW \& CCC \& CEIP Report, ISSN: 1504-6192, 181 pp., available at: http://emep.int/publ/reports/2012/status_report_1_2012. pdf, last access: 12 November 2012.

Ghani, A., Dexter, M., Carran, R. A., and Theobald, P. W.: Dissolved organic nitrogen and carbon in pastoral soils: the New Zealand experience, European J. Soil Sci., 58, 832-843, doi:10.1111/j.1365-2389.2006.00873.x, 2007.

Goodale, C. L., Aber, J. D., and McDowell, W. H.: The long-term effects of disturbance on organic and inorganic nitrogen export in the White Mountains, New Hampshire, Ecosystems, 3, 433-450, 2000.

Grayson, R. B., Gippel, C. J., Finlayson, B. L., and Hart, B. T.: Catchment-wide impacts on water quality: the use of "snapshot" sampling during stable flow, J. Hydrol., 199, 121-134, doi:10.1016/S0022-1694(96)03275-1, 1997.

Grieve, I. C.: Concentrations and annual loading of dissolved organic matter in a small moorland stream, Freshwater Biol., 14, 533-537, doi:10.1111/j.1365-2427.1984.tb00173.x, 1984.

Grieve, I. C.: Dissolved organic carbon dynamics in two streams draining forested catchments at Loch ard, Scotland, Hydrol. Process., 8, 457-464, doi:10.1002/hyp.3360080508, 1994.

Hansen, B., Thorling, L., Dalgaard, T., and Erlandsen, M.: Trend reversal of nitrate in Danish groundwater - a reflection of agricultural practices and nitrogen surpluses since 1950, Environ. Sci. Technol., 45, 228-234, 2011.

Hansen, B., Dalgaard, T., Thorling, L., Sørensen, B., and Erlandsen, M.: Regional analysis of groundwater nitrate concentrations and trends in Denmark in regard to agricultural influence, Biogeosciences, 9, 3277-3286, doi:10.5194/bg-9-3277-2012, 2012.
Hansen, J.: Land Use and Landscape development. Perspectives for nature, agriculture, environment and management, Extented Summary, DJF report no. 110 (markbrug), Foulum, Denmark, 15-29, 2004.

Hedin, L. O., Armesto, J. J., and Johnson, A. H.: Patterns of nutrient loss from unpolluted, old-growth temperate forests: evaluation of biogeochemical theory, Ecology, 76, 493-509, 1995.

Höll, A., Andersen, E., Rygnestad, H., Dalgaard, T., Sørensen, E. M., and Nilsson, K.: Scenario analyses for cultural landscape development, Danish Journal of Geography, 3, 1-12, 2002.

Hope, D., Billett, M. F., and Cresser, M. S.: A review of the export of carbon in river water: Fluxes and processes, Environ. Poll., 84, 301-324, doi:10.1016/0269-7491(94)90142-2, 1994.

Hutchings, N. J., Dalgaard, T., Rasmussen, B. M., Hansen, J. F., Dahl, M., Jörgensen, L. F., Ernstsen, V., von Platen-Hallermund, F., and Pedersen, S. S.: Watershed nitrogen modelling, in: Controlling Nitrogen Flows and Losses, edited by: Hatch, D. J., Chadwick, D. R., Jarvis, S. C., and Roker, J. A., Wageningen Academic Publishers, ISBN: 90-7699-984-34, 47-53, 2004.

Jobson, J. D.: Applied Multivariate Data Analysis: Regression and Experimental Design, Springer, 1991.

Kaiser, K. and Zech, W.: Sorption of dissolved organic nitrogen by acid subsoil horizons and individual mineral phases, Eur. J. Soil Sci., 51, 403-411, doi:10.1046/j.1365-2389.2000.00320.x, 2000.

Kalbitz, K., Solinger, S., Park, J. H., Michalzik, B., and Matzner, E.: Controls on the dynamics of dissolved organic matter in soils: a review, Soil Sci., 165, 277-304, 2000.

Keeney, D. R. and DeLuca, T. H.: Des Moines River nitrate in relation to watershed agricultural practices: 1945 versus 1980s, J. Environ. Qual., 22, 267-272, 1993.

Kennedy, J., Billett, M. F., Duthie, D., Fraser, A. R., and Harrison, A. F.: Organic matter retention in an upland humic podzol; the effects of $\mathrm{pH}$ and solute type, Eur. J. Soil Sci., 47, 615-625, doi:10.1111/j.1365-2389.1996.tb01860.x, 1996.

Kronvang, B., Jeppesen, E., Conley, D. J., Søndergaard, M., Larsen, S. E., Ovesen, N. B., and Carstensen, J.: Nutrient pressures and ecological responses to nutrient loading reductions in Danish streams, lakes and coastal waters, J. Hydrol., 304, 274-288, doi:10.1016/j.jhydrol.2004.07.035, 2005.

Kronvang, B., Andersen, H. E., Børgesen, C., Dalgaard, T., Larsen, S. E., Bøgestrand, J., and Blicher-Mathiasen, G.: Effects of policy measures implemented in Denmark on nitrogen pollution of the aquatic environment, Environ. Sci. Pol., 11, 144-152, doi:10.1016/j.envsci.2007.10.007, 2008.

Lajtha, K., Seely, B., and Valiela, I.: Retention and leaching losses of atmospherically-derived nitrogen in the aggrading coastal watershed of Waquoit Bay, MA, Biogeochemistry, 28, 33-54, doi:10.1007/BF02178060, 1995.

Lilienfein, J., Bridgham, S. D., Qualls, R. G., and Uselman, S. M.: Adsorption of dissolved organic carbon and nitrogen in soils of a weathering chronosequence, Soil Sci. Soc. Am. J., 68, 292-305, 2004.

Martin, C., Aquilina, L., Gascuel-Odoux, C., Molénat, J., Faucheux, M., and Ruiz, L.: Seasonal and interannual variations of nitrate and chloride in stream waters related to spatial and temporal patterns of groundwater concentrations in agricultural catchments, Hydrol. Process., 18, 1237-1254, doi:10.1002/hyp.1395, 2004.

Mattsson, T., Kortelainen, P., Laubel, A., Evans, D., Pujo-Pay, M., Räike, A., and Conan, P.: Export of dissolved organic matter in 
relation to land use along a European climatic gradient, Sci. Total Environ., 407, 1967-1976, doi:10.1016/j.scitotenv.2008.11.014, 2009.

McHale, M. R., Mitchell, M. J., McDonnell, J. J., and Cirmo, C. P.: Nitrogen solutes in an Adirondack forested watershed: Importance of dissolved organic nitrogen, Biogeochemistry, 48, 165184, doi:10.1023/A:1006121828108, 2000.

Michalzik, B. and Matzner, E.: Dynamics of dissolved organic nitrogen and carbon in a Central European Norway spruce ecosystem, Eur. J. Soil Sci., 50, 579-590, doi:10.1046/j.13652389.1999.00267.x, 1999.

Molénat, J., Durand, P., Gascuel-Odoux, C., Davy, P., and Gruau, G.: Mechanisms of Nitrate Transfer from Soil to Stream in an Agricultural Watershed of French Brittany, Water Air Soil Poll., 133, 161-183, 2002.

Moore, T. R.: Dissolved organic carbon in a northern boreal landscape, Global Biogeochem. Cy., 17, 1-8, 2003.

Murphy, D. V., Macdonald, A. J., Stockdale, E. A., Goulding, K. W. T., Fortune, S., Gaunt, J. L., Poulton, P. R., Wakefield, J. A., Webster, C. P., and Wilmer, W. S.: Soluble organic nitrogen in agricultural soils, Biol. Fert. Soils, 30, 374-387, doi:10.1007/s003740050018, 2000.

Näsholm, T., Kielland, K., and Ganeteg, U.: Uptake of organic nitrogen by plants, New Phytol., 182, 31-48, doi:10.1111/j.14698137.2008.02751.x, 2009.

National Environmental Research Institute, Denmark: Running Waters - Historical development and restoration of lowland Danish streams, Copenhagen, available at: http://www2.dmu.dk/1_ viden/2_Publikationer/3_Ovrige/rapporter/RW_web.pdf (last access: 12 November 2012), 2006.

Neff, J. C., Hobbie, S. E., and Vitousek, P. M.: Nutrient and mineralogical control on dissolved organic $\mathrm{C}, \mathrm{N}$ and $\mathrm{P}$ fluxes and stoichiometry in Hawaiian soils, Biogeochemistry, 51, 283-302, 2000.

Neff, J. C., Holland, E. A., Dentener, F. J., McDowell, W. H., and Russell, K. M.: The origin, composition and rates of organic nitrogen deposition: A missing piece of the nitrogen cycle?, Biogeochemistry, 57, 99-136, 2002.

Neff, J. C., Chapin III, F. S., and Vitousek, P. M.: Breaks in the cycle: dissolved organic nitrogen in terrestrial ecosystems, Front. Ecol. Environ., 1, 205-211, 2003.

Perakis, S. S.: Nutrient limitation, hydrology and watershed nitrogen loss, Hydrol. Process., 16, 3507-3511, doi:10.1002/hyp.5078, 2002.

PlanteInfo: available at: http://www.planteinfo.dk/Vejret/ 2008/index.asp?item_id=649 \\&appl=0 $\backslash \& \_s e s s i o n i d=$ DTzWYlw9M52 \\&_server=172.23.173.222 \\&_port=5007 \&pi_menu=1 \\&Fuzz=719 (last access: 30 May 2011), 2011.

Poor, C. J. and McDonnell, J. J.: The effects of land use on stream nitrate dynamics, J. Hydrol., 332, 54-68, doi:10.1016/j.jhydrol.2006.06.022, 2007.

Randall, G. W.: Implications of dry and wet cycles on nitrate loss to subsurface tile drainage, in: Proc. 7th Annu. Drainage Symp., Orlando, FL, 8-10 March 1998, Drainage in the 21st Century, American Society of Agricultural Engineers, St. Joseph, MI, 5360, 1998.

Randall, G. W. and Mulla, D. J.: Nitrate Nitrogen in Surface Waters as Influenced by Climatic Conditions and Agricultural Practices, J. Environ. Qual., 30, 337-344, 2001.
Ruiz, L., Abiven, S., Durand, P., Martin, C., Vertès, F., and Beaujouan, V.: Effect on nitrate concentration in stream water of agricultural practices in small catchments in Brittany: I. Annual nitrogen budgets, Hydrol. Earth Syst. Sci., 6, 497-506, doi:10.5194/hess-6-497-2002, 2002a.

Ruiz, L., Abiven, S., Martin, C., Durand, P., Beaujouan, V., and Molénat, J.: Effect on nitrate concentration in stream water of agricultural practices in small catchments in Brittany: II. Temporal variations and mixing processes, Hydrol. Earth Syst. Sci., 6, 507-514, doi:10.5194/hess-6-507-2002, 2002b.

Sand-Jensen, K. and Pedersen, N. L.: Differences in temperature, organic carbon and oxygen consumption among lowland streams, Freshwater Biol., 50, 1927-1937, doi:10.1111/j.13652427.2005.01436.x, 2005.

Scheffer, F. and Schachtschabel, P.: Lehrbuch der Bodenkunde, Spektrum Akademischer Verlag GmbH, 2002.

Schelde, K., Cellier, P., Bertolini, T., Dalgaard, T., Weidinger, T., Theobald, M. R., and Olesen, J. E.: Spatial and temporal variability of nitrous oxide emissions in a mixed farming landscape of Denmark, Biogeosciences, 9, 2989-3002, doi:10.5194/bg-92989-2012, 2012.

Schiff, S. L., Devito, K. J., Elgood, R. J., McCrindle, P. M., Spoelstra, J., and Dillon, P.: Two adjacent forested catchments: Dramatically different $\mathrm{NO}_{3}^{-}$export, Water Resour. Res., 38, 1292, doi:10.1029/2000WR000170, 2002.

Schnabel, R. R., Urban, J. B., and Gburek, W. J.: Hydrologic controls in nitrate, sulfate, and chloride concentrations, J. Environ. Qual., 22, 589-596, 1993.

Siemens, J. and Kaupenjohann, M.: Contribution of dissolved organic nitrogen to $\mathrm{N}$ leaching from four German agricultural soils, J. Plant Nutr. Soil Sc., 165, 675-681, doi:10.1002/jpln.200290002, 2002.

SPSS Inc.: Systat for Windows, Version 15.0.1 SPSS Inc., Chicago, IL, USA, 2006.

Steenvoorden, J. H. A. M., Claessen, F., and Willems, J.: Agricultural effects on ground and surface waters: research at the edge of science and society, IAHS-AISH P., Publication no. 273, 71 pp., 2002.

Vagstad, N., Stålnacke, P., Andersen, H.-E., Deelstra, J., Jansons, V., Kyllmar, K., Loigu, E., Rekolainen, S., and Tumas, R.: Regional variations in diffuse nitrogen losses from agriculture in the Nordic and Baltic regions, Hydrol. Earth Syst. Sci., 8, 651662, doi:10.5194/hess-8-651-2004, 2004.

van Breemen, N.: Nitrogen cycle: Natural organic tendency, Nature, 415, 381-382, doi:10.1038/415381a, 2002.

van Kessel, C., Clough, T., and van Groenigen, J. W.: Dissolved Organic Nitrogen: An Overlooked Pathway of Nitrogen Loss from Agricultural Systems?, J. Environ. Qual., 38, 393-401, doi:10.2134/jeq2008.0277, 2009.

Vitousek, P. M., Aber, J. D., Howarth, R. W., Likens, G. E., Matson, P. A., Schindler, D. W., Schlesinger, W. H., and Tilman, D. G.: Human alteration of the global nitrogen cycle: sources and consequences, Ecol. Appl., 7, 737-750, doi:10.1890/10510761(1997)007[0737:HAOTGN]2.0.CO;2, 1997.

Willett, V. B., Reynolds, B. A., Stevens, P. A., Ormerod, S. J., and Jones, D. L.: Dissolved organic nitrogen regulation in freshwaters, J. Environ. Qual., 33, 201-209, 2004.

Wilson, J. P. and Gallant, J. C.: Terrain analysis: principles and applications, John Wiley and Sons., 2000. 
Worrall, F. and Burt, T. P.: Inter-annual controls on nitrate export from an agricultural catchment - how much land-use change is safe?, J. Hydrol., 243, 228-241, doi:10.1016/S00221694(00)00411-X, 2001.

Worrall, F., Burt, T. P., Jaeban, R. Y., Warburton, J., and Shedden, R.: Release of dissolved organic carbon from upland peat, Hydrol. Process., 16, 3487-3504, doi:10.1002/hyp.1111, 2002.
Worrall, F., Harriman, R., Evans, C. D., Watts, C. D., Adamson, J., Neal, C., Tipping, E., Burt, T., Grieve, I., Monteith, D., Naden, P. S., Nisbet, T., Reynolds, B., and Stevens, P.: Trends in Dissolved Organic Carbon in UK Rivers and Lakes, Biogeochemistry, 70, 369-402, doi:10.1007/s10533-004-8131-7, 2004. 